Article

\title{
Improvement of the Corrosion Resistance by Addition of Ni in Lean Duplex Stainless Steels
}

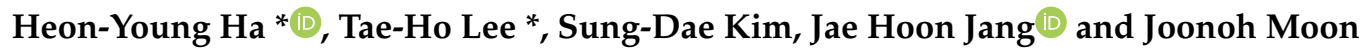 \\ Ferrous Alloy Department, Korea Institute of Materials Science, Changwon 51508, Korea; \\ sdkim@kims.re.kr (S.-D.K.); jhjang@kims.re.kr (J.H.J.); mjo99@kims.re.kr (J.M.) \\ * Correspondence: hyha2007@kims.re.kr (H.-Y.H.); lth@kims.re.kr (T.-H.L.); Tel.: +82-55-280-3422 (H.-Y.H.); \\ +82-55-280-3434 (T.-H.L.); Fax: +82-55-280-3599 (H.-Y.H. \& T.-H.L.)
}

Received: 29 May 2020; Accepted: 3 July 2020; Published: 4 July 2020

\begin{abstract}
On newly developed Fe balance $^{-18 C r-7 M n-3 M o-3 W-0.4 N-(0.03, ~ 0.57) N i ~(i n ~ w t ~} \%$ ) lean duplex stainless steels, the microstructure, element partitioning behavior, and resistance to pitting corrosion were investigated. After solution treatments, the two alloys were found to have similar microstructures in terms of phase fraction and grain size, and have a precipitation-free matrix. The polarization tests revealed that the addition of $\mathrm{Ni}$ was beneficial to improve the resistance to pitting corrosion, which was confirmed by the rise in pitting and repassivation potentials. The uniform corrosion behavior and galvanic corrosion rate of the matrix were investigated to explain the improved pitting corrosion resistance of the Ni-added lean duplex stainless steel. As a result, it was found that the addition of $\mathrm{Ni}$ enhanced the resistance to uniform corrosion by reducing the galvanic corrosion rate between the ferrite and austenite phases in the lean duplex stainless steel; thus, the pit growth rate was decreased, leading to improvement of the resistance to pitting corrosion.
\end{abstract}

Keywords: lean duplex stainless steel; pitting corrosion; galvanic corrosion; nickel

\section{Introduction}

Duplex stainless steels (DSSs) have a dual-phase structure composed of approximately equal amounts of ferrite $(\alpha)$ phase and austenite $(\gamma)$. The DSSs possess good combination of mechanical and corrosion properties, and they are well known for excellent resistance to stress corrosion cracking in comparison with single-phase stainless steels (SSs) [1-10]. In addition, DSSs are economically attractive because commercial DSSs commonly contain only $1-7 \mathrm{wt} \% \mathrm{Ni}$, which is less than the Ni content of FeCrNi-based $\gamma$-SS (8-24 wt\%) $[2,6,9,11]$. These advantages of DSSs make them promising alternatives to $\gamma$-SSs, and thus, demands for DSSs show a continuous increase in various industrial fields such as the on/off-shore oil and gas industry and chemical process industry [2,3,5,12-14].

Economic feasibility of DSSs can be further achieved by reducing the amount of expensive alloying elements, particularly Ni. Thus, various lean-DSSs (LDSSs), in which Ni is replaced with other $\gamma$ stabilizers, such as Mn and N, have been developed and investigated [1,14-18]. Recently, this author group has proposed new LDSSs [17,19], which comprise 16.5-19.5 $\mathrm{wt} \% \mathrm{Cr}, 2.5-3.5 \mathrm{wt} \% \mathrm{Mo}, 1.0-3.5 \mathrm{wt} \%$ $\mathrm{W}, 5.5-7.0 \mathrm{wt} \% \mathrm{Mn}, 0.35-0.45 \mathrm{wt} \% \mathrm{~N}$, and less than $0.7 \mathrm{wt} \% \mathrm{Ni}$ with a remainder of Fe. The developed LDSSs are characterized by their excellent mechanical performances. The LDSSs are found to have the yield strengths of 574-635 MPa and the tensile strengths of $826-878 \mathrm{MPa}$, which are much higher than those of commercial $\gamma$-SSs, such as UNS S30400 and S31603, and even better than commercial DSSs, UNS S32304 and S31803. In addition, the LDSSs exhibit high elongation values of 40-51\%, which are notable levels for general DSSs and comparable to commercial $\gamma$-SS. Moreover, it is revealed that the resistance to localized corrosion of the LDSSs is superior to that of UNS S31603 alloy. Thus, considering 
the desirable combination of the mechanical and corrosion properties of the LDSSs, it can be concluded that the developed LDSSs have the potential to be applied to industrial field.

From an economical point of view, the use of $\mathrm{Ni}$ is intentionally limited for LDSSs as mentioned above. However, the authors have found that a small amount of $\mathrm{Ni}$ less than $1 \mathrm{wt} \%$ is useful to improve the localized corrosion resistance of LDSS, although $\mathrm{Ni}$ is generally known to have little effect on the pitting corrosion resistance in neutral $\mathrm{NaCl}$ solutions [20-22]. Thus, in this paper, Fe $_{\text {balance }}-18 \mathrm{Cr}-7 \mathrm{Mn}-3 \mathrm{Mo}-3 \mathrm{~W}-0.4 \mathrm{~N}-$ based (in wt $\%$ ) LDSSs with and without Ni were fabricated, and the microstructures, element partitioning, and the pitting corrosion resistance of the LDSSs were examined. Then, the role of alloying $\mathrm{Ni}$ in the resistance to pitting corrosion of the LDSSs was discussed.

\section{Materials and Methods}

In this study, $\mathrm{Fe}_{\text {balance }}-18 \mathrm{Cr}-7 \mathrm{Mn}-3 \mathrm{Mo}-3 \mathrm{~W}-0.4 \mathrm{~N}$-based (in wt\%) LDSSs containing different concentrations of $\mathrm{Ni}(0.03$ and $0.57 \mathrm{wt} \%)$ were investigated. The Ni content needs to be adjusted to $0.6 \mathrm{wt} \%$ or less in order to prevent the solution treatment temperature from becoming too high. The detailed chemical compositions of the LDSSs, denoted as Ni03 and Ni57, are given in Table 1, which were measured using optical emission spectroscopy (QSN 750-II, PANalytical, Almemo, the Netherlands) and inductively coupled plasma atomic emission spectroscopy (Optima 8300DV, PerkinElmer, Waltham, MA, USA).

Table 1. Chemical compositions (in $\mathrm{w} t \%$ ) of the investigated alloys measured using optical emission spectroscopy and inductively coupled plasma atomic emission spectroscopy.

\begin{tabular}{ccccccccc}
\hline Alloy & Fe & Cr & Mo & W & Ni & Mn & N & C \\
\hline Ni03 & Balance & $18.35 \pm 0.032$ & $2.98 \pm 0.019$ & $3.02 \pm 0.035$ & $0.03 \pm 0.007$ & $6.64 \pm 0.031$ & $0.42 \pm 0.002$ & $0.013 \pm 0.002$ \\
\hline Ni57 & Balance & $17.99 \pm 0.027$ & $2.94 \pm 0.021$ & $3.09 \pm 0.036$ & $0.57 \pm 0.012$ & $6.65 \pm 0.026$ & $0.42 \pm 0.002$ & $0.012 \pm 0.002$ \\
\hline
\end{tabular}

The LDSS ingots of $10 \mathrm{~kg}$ were fabricated through pressurized induction melting (VIM 4 III-P, ALD Vacuum Technologies $\mathrm{GmbH}$, Hanau, German) under an $\mathrm{N}_{2}$ atmosphere. The ingots were homogenized at $1250{ }^{\circ} \mathrm{C}$ for $2 \mathrm{~h}$ and hot-rolled onto plates with a thickness of $4 \mathrm{~mm}$, followed by water quenching. Then, the hot-rolled plates were solution-treated at 1100 and $1180{ }^{\circ} \mathrm{C}$ for $30 \mathrm{~min}$, respectively, in order to obtain dual-phase structure with a phase fraction $(\alpha: \gamma)$ of approximately 1:1. The temperatures for the solution treatments were determined based on the diagrams of the equilibrium phase fraction versus temperature (Figure 1), which were calculated using Thermo-Calc software (version 2019a, database TCFE 9.0, Thermo-Calc Software, Stockholm, Sweden (KTH)).

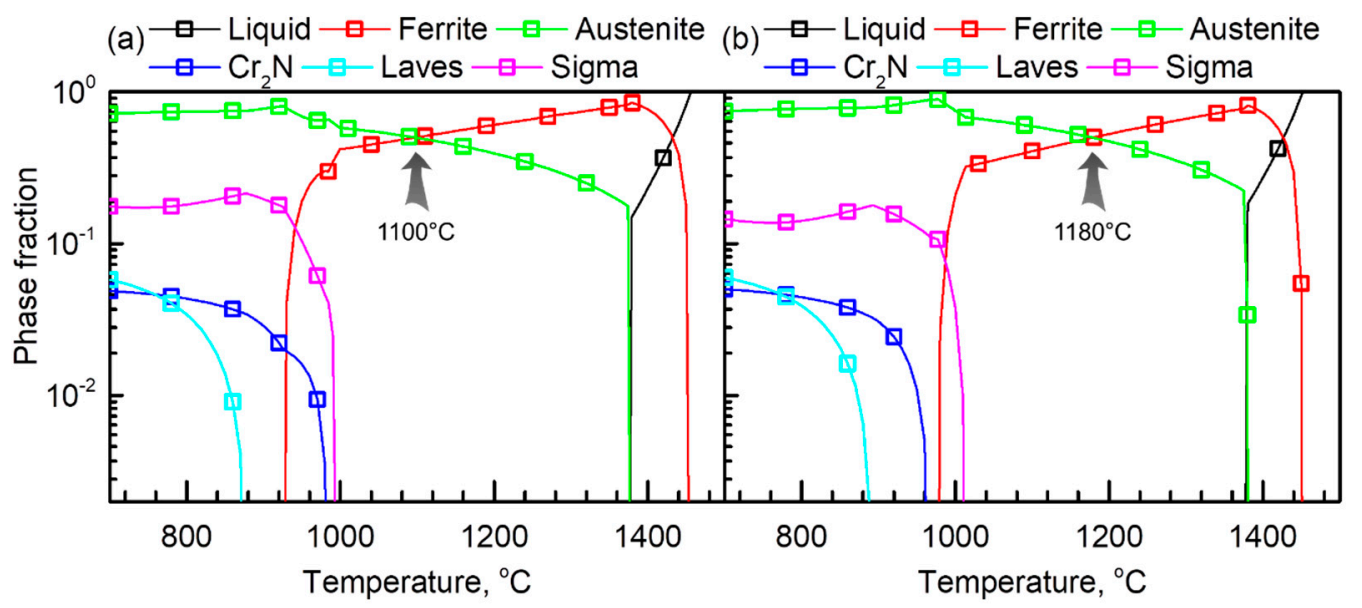

Figure 1. Equilibrium phase fractions of (a) Ni03 and (b) Ni57 alloys as a function of temperature calculated using Thermo-Calc software (version 2019a, TCFE 9.0 database). 
Microstructures of the LDSSs were examined using a scanning electron microscope (SEM, IT-300, JEOL, Akishima, Japan) and electron backscatter diffraction (EBSD, HKL Nordlys Channel 5, Oxford Instruments, Abingdon, UK) in a SEM (JSM-7001F, JEOL, Akishima, Japan). For the SEM analyses, the LDSS specimens $(10 \mathrm{~mm} \times 10 \mathrm{~mm} \times 4 \mathrm{~mm})$ were polished using suspension with $1 \mu \mathrm{m}$-sized diamond particles, and chemically etched in an acid mixture $\left(20 \mathrm{~mL} \mathrm{HNO}_{3}+30 \mathrm{~mL} \mathrm{HCl}+50 \mathrm{~mL}\right.$ deionized water) for 1-3 min. For the EBSD analyses, the specimens were polished using colloidal silica with a particle size of $0.02 \mu \mathrm{m}$. The EBSD analysis was performed on a scanning area $150 \mu \mathrm{m} \times 120 \mu \mathrm{m}$ with a step size of $0.5 \mu \mathrm{m}$, and the grain boundaries were identified with the critical misorientation angle of $10^{\circ}$. From the EBSD images taken at 5 different locations, average values of the phase fractions $(\alpha: \gamma$, in $v o l \%$ ) and grain sizes were measured. Then, the chemical compositions of the $\alpha$ and $\gamma$ phases in the LDSSs were examined through an electron probe microanalysis (EPMA, SX100, CAMECA, Gennevilliers, France). For each alloy and each phase, 10 points were analyzed using the EPMA, and the average values were calculated.

Corrosion properties of the Ni03 and Ni57 alloys were evaluated through electrochemical tests. All of the electrochemical tests were performed using a three-electrode glass cell consisting of a saturated calomel reference electrode (SCE), a Pt plate counter electrode, and a specimen serving as a working electrode. For the working electrode, the LDSS specimens were mounted in cold epoxy resin and ground using SiC emery paper of up to 1500 grit. The exposed area for the test was controlled to be $0.2 \mathrm{~cm}^{2}$ using electroplating tape. The tests were controlled by a potentiostat (Reference600+, GAMRY, Warminster, PA, USA).

The pitting corrosion resistance and repassivation tendencies of the LDSSs were evaluated through cyclic polarization tests in a $2 \mathrm{M} \mathrm{NaCl}$ solution at $40^{\circ} \mathrm{C}$. Based on our previous experiments, the LDSSs were immune to pitting corrosion, even in a $2 \mathrm{M} \mathrm{NaCl}$ solution at room temperature; thus, the polarization tests were performed in a $2 \mathrm{M} \mathrm{NaCl}$ solution and the solution temperature was controlled to be $40{ }^{\circ} \mathrm{C}$. The specimens were immersed in the solution for $20 \mathrm{~min}$ prior to the potentiodynamic polarization tests for stabilization, from which the stable open circuit potential (OCP) was measured. After that, the potential was anodically increased from $-0.1 \mathrm{~V}$ versus OCP to the potential at which the current density exceeded $0.1 \mathrm{~mA} \mathrm{~cm}^{-2}$, and then, lowered to the repassivation potential $\left(\mathrm{E}_{\mathrm{rp}}\right)$, with a potential sweep rate of $0.17 \mathrm{mV} \mathrm{s}^{-1}$. Then, the dissolution rate after the stable pit formation was measured through potentiostatic tests. In the same condition ( $2 \mathrm{M} \mathrm{NaCl}$ solution at $40{ }^{\circ} \mathrm{C}$ ), anodic constant potentials of 0.10 and $0.35 \mathrm{~V}_{\mathrm{SCE}}$ were applied to the specimen for $20 \mathrm{~min}$, and the current versus time curves were recorded.

For the two LDSSs, the sites for the pitting corrosion were observed using the SEM after immersion in a $2 \mathrm{M} \mathrm{NaCl}+1 \mathrm{M} \mathrm{HCl}$ solution at $40^{\circ} \mathrm{C}$ under the $\mathrm{OCP}$ for $30 \mathrm{~min}$. The strong acid containing $\mathrm{Cl}^{-}$was needed for this experiment in order to simultaneously identify the phase boundary and the pit sites.

Uniform (or general) corrosion behavior of the LDSSs was examined through polarization tests in a $1 \mathrm{M} \mathrm{HCl}$ solution at $40{ }^{\circ} \mathrm{C}$. After the OCP reached a steady state, the potential was scanned at a rate of $0.17 \mathrm{mV} \mathrm{s}^{-1}$ in the potential range for the active-passive transition. Then, the galvanic corrosion rate between the $\alpha$ and $\gamma$ phases in the LDSS was quantified by measuring the corrosion depth between the two phases $[10,17,23-25]$. The polished specimens were immersed in a $1 \mathrm{M} \mathrm{HCl}$ solution at $40^{\circ} \mathrm{C}$, and after $20 \mathrm{~min}$ of immersion, the three-dimensional corroded morphology and the corrosion depth were examined using a surface optical profiler (Wyko NT8000, Veeco, Plainview, NY, USA). All of the potentiodynamic and potentiostatic tests were repeated at least five times for each specimen to verify reproducibility.

\section{Results}

\subsection{Microstructure}

Figure $1 \mathrm{a}, \mathrm{b}$ show equilibrium fractions of the liquid, $\alpha, \gamma, \mathrm{Cr}_{2} \mathrm{~N}$, Laves, and sigma $(\sigma)$ phase in the $\mathrm{Ni} 03$ and Ni57 alloys, respectively. In the two LDSSs, $\mathrm{Cr}_{2} \mathrm{~N}$, Laves, and the $\sigma$ phases are expected to 
precipitate at below approximately $1000^{\circ} \mathrm{C}$, and the dual-phase without precipitates can be obtained in the temperature range between approximately 1000 and $1350^{\circ} \mathrm{C}$. In order to control the phase fraction $(\alpha: \gamma)$ to be $1: 1,1100{ }^{\circ} \mathrm{C}$ was determined for the solution treatment for the Ni03 alloy. On the other hand, the addition of $\mathrm{Ni}$ to the $\mathrm{Ni03}$ alloy expands the temperature range for the stable $\gamma$, thus, the solution treatment temperature for the $\mathrm{Ni57}$ was determined as $1180{ }^{\circ} \mathrm{C}$.

Figure 2a,b exhibit SEM images of the microstructure solution-treated Ni03 and Ni57 alloys, respectively. After the solution treatment, the $\alpha$ and $\gamma$ phases coexisted in both LDSSs, as shown in Figure 2(a-1),(b-1). The relatively light grey phase was the $\alpha$ phase and the dark grey phase with annealing twin was the $\gamma$ phase, as marked in the SEM images. In addition, nonmetallic inclusions, which possibly act as initiation sites for localized corrosion [26-28], were rarely observed. The magnified SEM images (Figure 2(a-2),(b-2)) show that the precipitations, such as $\mathrm{Cr}_{2} \mathrm{~N}$ and $\sigma$, were not observed, even at the grain boundaries in both LDSSs.
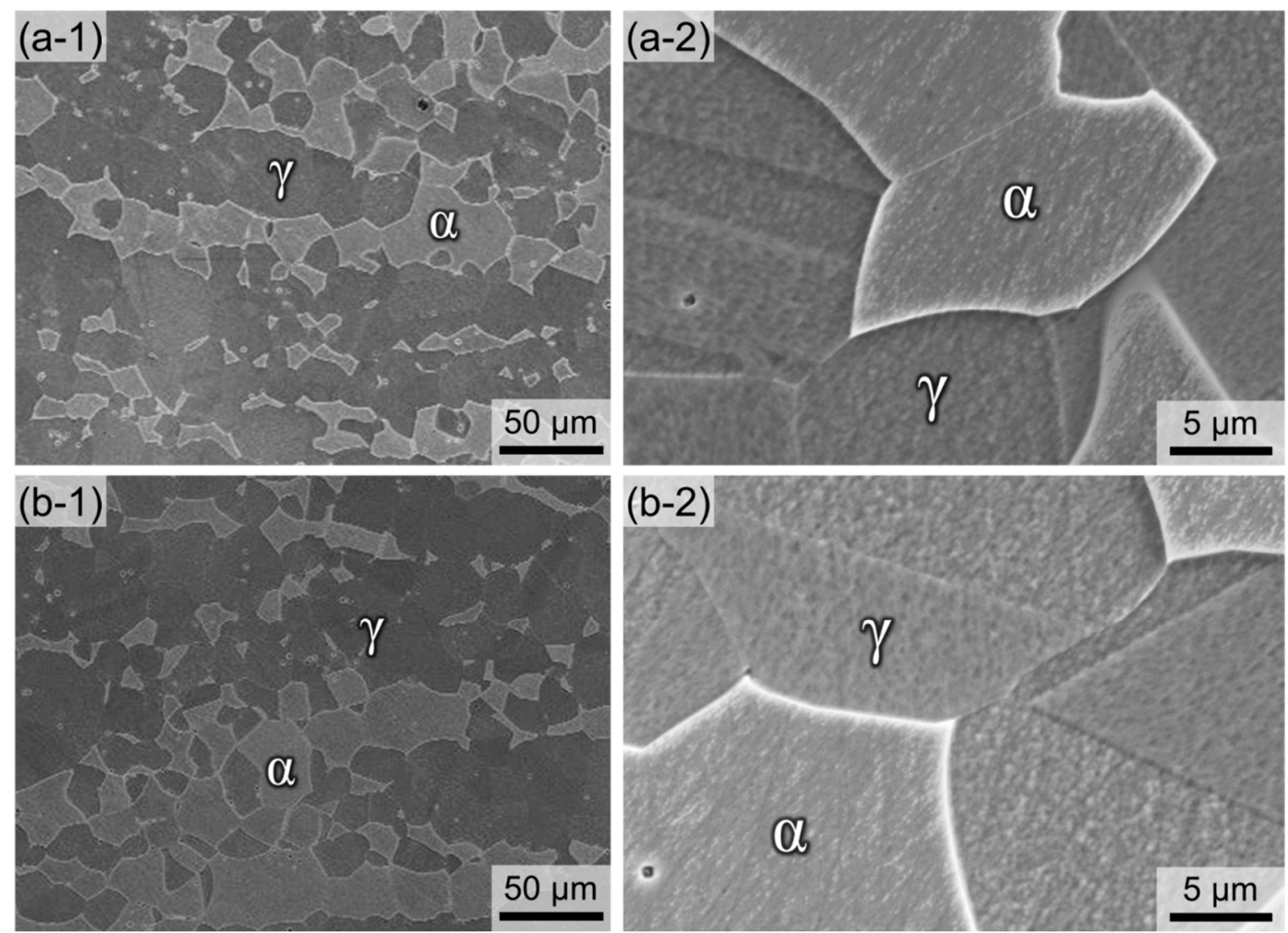

Figure 2. Microstructures of (a-1,a-2) Ni03 and (b-1,b-2) Ni57 alloys observed using a SEM taken at $(\mathbf{a}-\mathbf{1}, \mathbf{b}-\mathbf{1})$ low and $(\mathbf{a}-\mathbf{2}, \mathbf{b}-\mathbf{2})$ high magnifications.

The phase fraction and grain size were measured using EBSD analyses. Figure 3(a-1,b-1) are grey scale image quality maps of the Ni03 and Ni57 alloys, respectively, and Figure 3(a-2,b-2) are the corresponding phase maps of the LDSSs. The $\alpha$ phase fraction of the Ni03 alloy was measured to be $49.8 \mathrm{vol} \%$ and that of the Ni57 alloy was $48.4 \mathrm{vol} \%$. The average grain sizes of the two LDSSs are presented in Table 2 and Figure 3c. The grain sizes of the $\alpha$ phases of the Ni03 and Ni57 alloys were 12.24 and $12.37 \mu \mathrm{m}$, respectively, and those of the $\gamma$ phases were 9.87 and $10.88 \mu \mathrm{m}$ for the Ni03 and Ni57 alloys, respectively. The two LDSSs were generally similar in grain sizes, but the Ni57 alloy had marginally larger grain in comparison with that of the Ni03 alloy, which was due to the higher solution treatment temperature for the Ni57 alloy. 

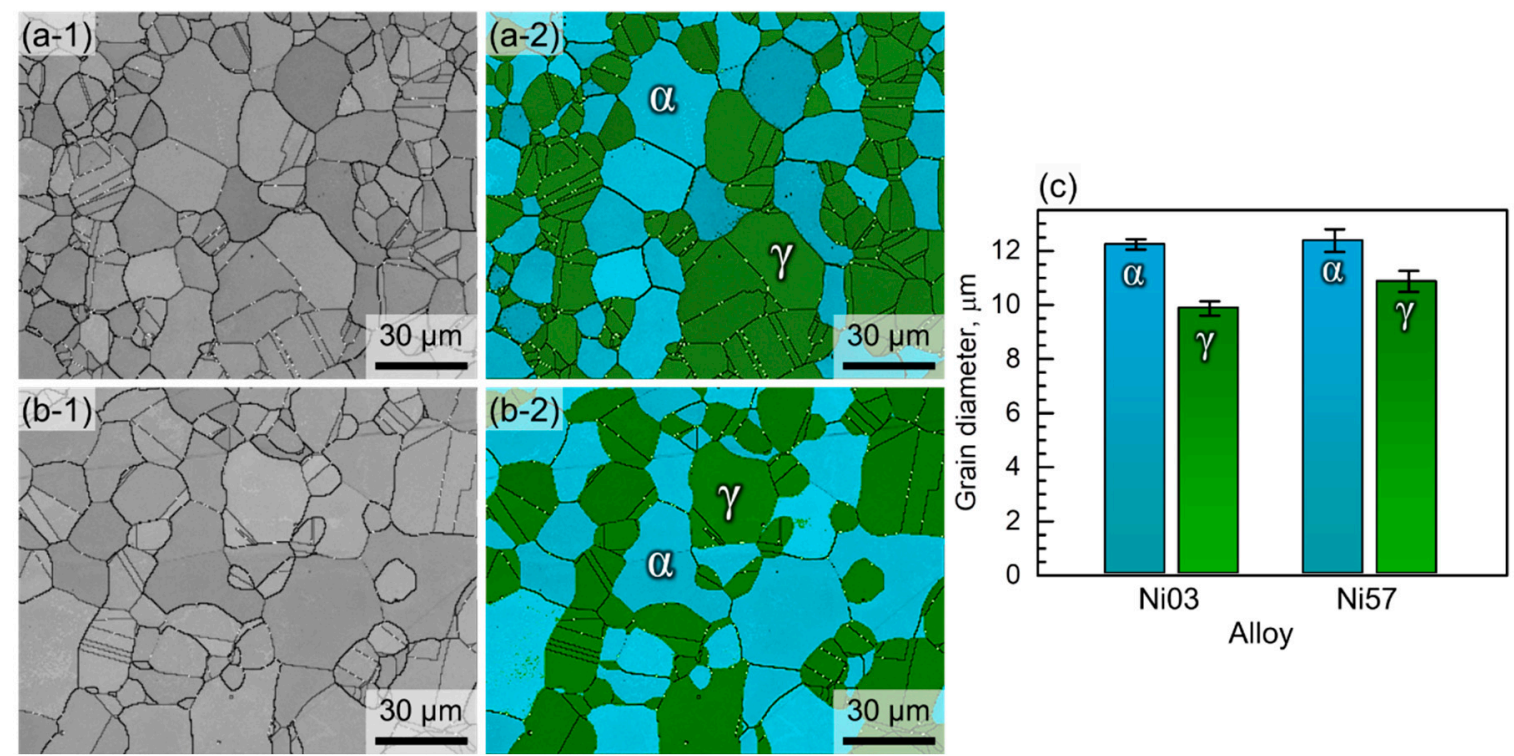

Figure 3. EBSD image quality maps of (a-1) Ni03 and (b-1) Ni57 alloys and phase maps of (a-2) Ni03 and (b-2) Ni57 alloys (green-face-centered cubic $(\gamma)$ and blue-body centered cubic $(\alpha)$ ). (c) Grain diameters of the $\alpha$ and $\gamma$ phases in the Ni03 and Ni57 alloys.

Table 2. Chemical compositions (in wt \%) of the $\alpha$ and $\gamma$ phases of the Ni03 and Ni57 alloys measured using an EPMA.

\begin{tabular}{|c|c|c|c|c|c|c|c|c|c|c|}
\hline \multirow{2}{*}{ Alloy } & \multirow{2}{*}{ Phase } & \multirow{2}{*}{$\begin{array}{c}\text { Grain Diameter, } \\
\mu \mathrm{m}\end{array}$} & \multicolumn{8}{|c|}{ Concentration, wt $\%$} \\
\hline & & & $\mathrm{Fe}$ & $\mathrm{Cr}$ & Mo & W & Mn & $\mathbf{N}$ & $\mathrm{Ni}$ & PREN \\
\hline \multirow[b]{2}{*}{$\mathrm{Ni03}$} & $\alpha$ & $12.24 \pm 0.19$ & \multirow[b]{2}{*}{ Balance } & $17.945 \pm 0.078$ & $3.628 \pm 0.041$ & $3.814 \pm 0.039$ & $6.157 \pm 0.047$ & $0.022 \pm 0.009$ & $0.041 \pm 0.017$ & 30.406 \\
\hline & $\gamma$ & $9.87 \pm 0.26$ & & $18.674 \pm 0.063$ & $2.122 \pm 0.065$ & $2.452 \pm 0.027$ & $7.233 \pm 0.063$ & $0.690 \pm 0.017$ & $0.021 \pm 0.006$ & 33.529 \\
\hline \multirow{2}{*}{ Ni57 } & $\alpha$ & $12.37 \pm 0.42$ & \multirow{2}{*}{ Balance } & $17.723 \pm 0.064$ & $3.506 \pm 0.044$ & $3.820 \pm 0.027$ & $6.108 \pm 0.079$ & $0.015 \pm 0.006$ & $0.423 \pm 0.020$ & 29.728 \\
\hline & $\gamma$ & $10.88 \pm 0.39$ & & $18.202 \pm 0.057$ & $2.269 \pm 0.053$ & $2.449 \pm 0.031$ & $7.120 \pm 0.072$ & $0.659 \pm 0.039$ & $0.679 \pm 0.036$ & 33.155 \\
\hline
\end{tabular}

\subsection{Alloying Element Partitioning}

Table 2 and Figure 4 show the chemical compositions of the $\alpha$ and $\gamma$ phases of the Ni03 and Ni57 alloys, which were examined using the EPMA. After the solution treatment, the concentrations of Mo (Figure $4 b$ ) and W (Figure 4c), the $\alpha$ stabilizer, are higher in the $\alpha$ phase than in the $\gamma$ phase by approximately $1.5 \mathrm{wt} \%$. As for another $\alpha$ stabilizer, the partitioning behavior of $\mathrm{Cr}$ in the Ni03 and Ni57 alloys was noticeable (Figure 4a). The Cr content in the bulk matrix of the Ni57 alloy was lower than that of the Ni03 alloy, thus, the difference in the Cr content between the two LDSSs was shown in Figure 4a. The notable point is that the $\gamma$ phases in both Ni03 and Ni57 alloys contain higher $\mathrm{Cr}$ than the $\alpha$ phases, although $\mathrm{Cr}$ is the $\alpha$ stabilizer. A similar result can be found in the N-bearing DSSs

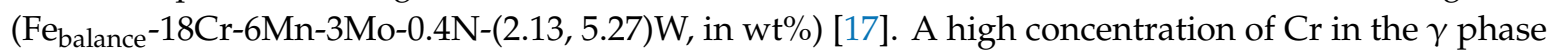
is presumably due to the strong affinity between $\mathrm{N}$ and $\mathrm{Cr}$. The $\mathrm{Cr}$-partitioning behavior is slightly affected by the Ni addition to the matrix, that is, the difference in the $\mathrm{Cr}$ concentrations between the $\alpha$ and $\gamma$ phases of the Ni03 alloy was $0.73 \mathrm{wt} \%$ and that of the Ni57 alloy was decreased to $0.48 \mathrm{wt} \%$. As for the $\gamma$ stabilizers, Mn (Figure 4d), N (Figure 4e), and Ni (Figure 4f) were enriched in the $\gamma$ phases in both DSSs, and the partitioning of Mn and $\mathrm{N}$ was hardly affected by the presence of Ni in the Ni03 matrix, as shown in Figure 4d,e. Lastly, the partitioning of Ni was shown in Figure $4 \mathrm{f}$. The $\gamma$ phase of the Ni57 alloy contained $0.68 \mathrm{wt} \% \mathrm{Ni}$, while the $\alpha$ phase has only $0.42 \mathrm{wt} \% \mathrm{Ni}$. 

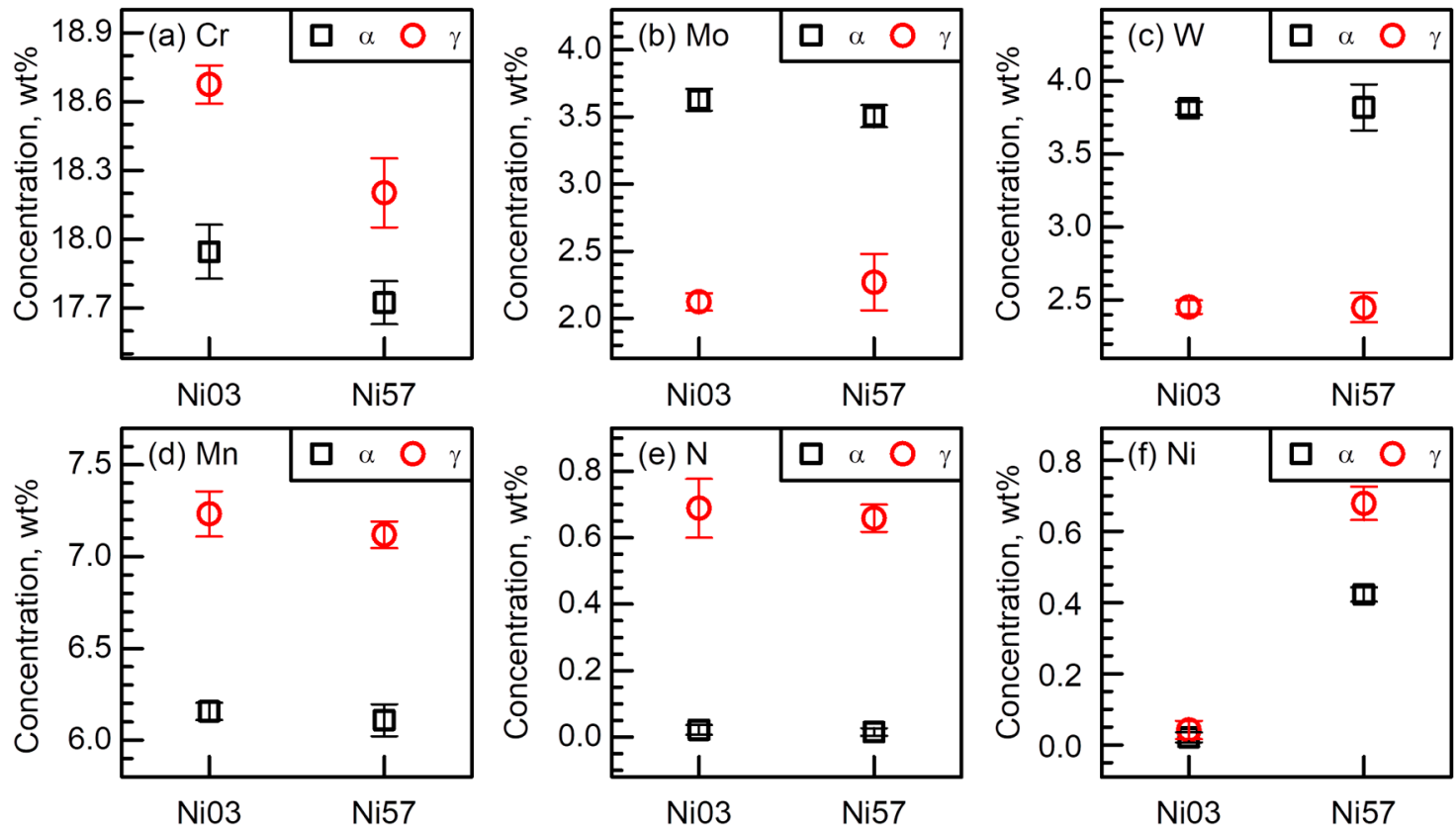

Figure 4. Chemical compositions of (a) $\mathrm{Cr}(\mathbf{b}) \mathrm{Mo},(\mathbf{c}) \mathrm{W},(\mathbf{d}) \mathrm{Mn},(\mathbf{e}) \mathrm{N}$, and (f) $\mathrm{Ni}$ of the $\alpha$ and $\gamma$ phases in the Ni03 and Ni57 alloys measured using the EPMA.

\subsection{Pitting Corrosion Behavior}

The resistance to pitting corrosion of the LDSSs was assessed through cyclic potentiodynamic polarization tests. From the repeatedly obtained polarization curves, three representative results for each LDSS were presented in Figure 5, verifying reproducibility. From the polarization tests, pitting potential $\left(\mathrm{E}_{\mathrm{pit}}\right)$ and $\mathrm{E}_{\mathrm{rp}}$ could be obtained, and the average values of $\mathrm{E}_{\mathrm{pit}}$ and $\mathrm{E}_{\mathrm{rp}}$ were plotted in Figure $5 \mathrm{c}$ as a function of the $\mathrm{Ni}$ content ([Ni]).
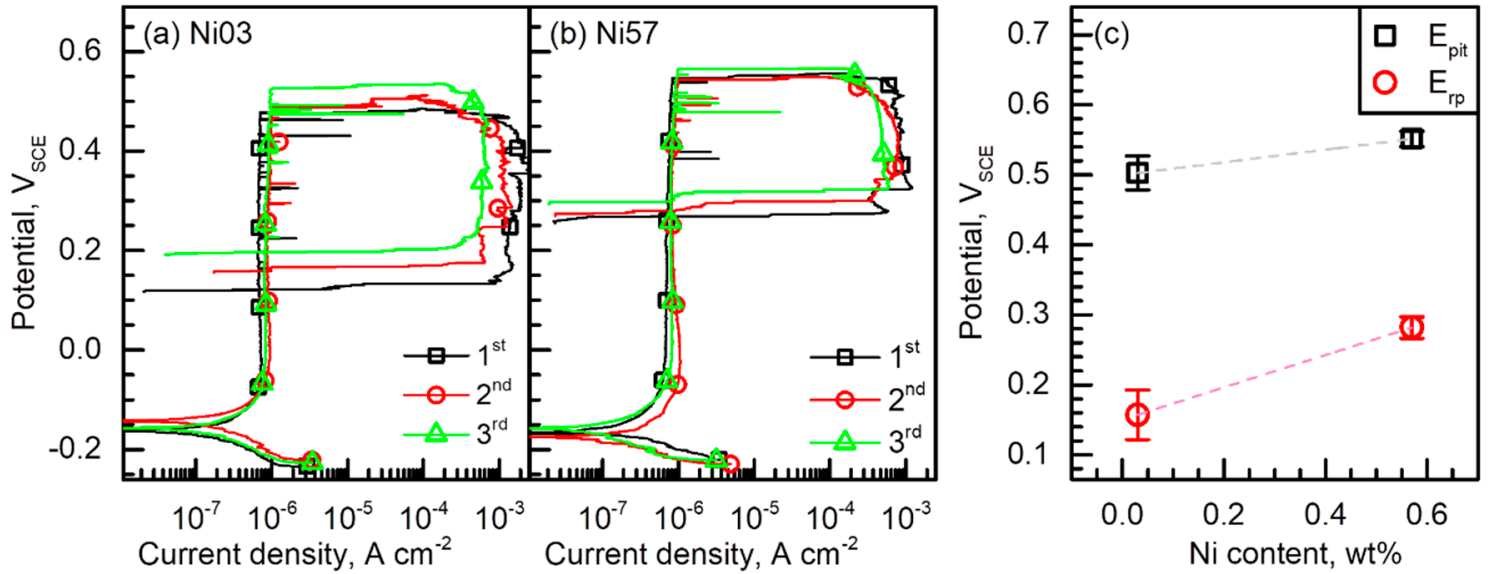

Figure 5. Repeatedly measured cyclic potentiodynamic polarization curves of (a) Ni03 and (b) Ni57 alloys. The polarization tests were obtained in $2 \mathrm{M} \mathrm{NaCl}$ at $40{ }^{\circ} \mathrm{C}$ with a potential sweep rate of $0.17 \mathrm{mV} \mathrm{s}^{-1}$. (c) Average pitting potential $\left(\mathrm{E}_{\mathrm{pit}}\right)$ and repassivation potential $\left(\mathrm{E}_{\mathrm{rp}}\right)$ of the alloys.

Corrosion potential ( $\mathrm{E}_{\mathrm{corr}}$ ) of the Ni03 and Ni57 alloys were -0.151 and $-0.158 \mathrm{~V}_{\mathrm{SCE}}$, respectively, and both LDSSs were in passive state at their $\mathrm{E}_{\text {corr }}$ levels. Comparing Figure $5 \mathrm{a}, \mathrm{b}$, it is obvious that the $\mathrm{Ni}$ addition changed both $\mathrm{E}_{\mathrm{pit}}$ and $\mathrm{E}_{\mathrm{rp}}$ (Figure 5). The average $\mathrm{E}_{\mathrm{pit}}$ of the Ni03 and Ni57 alloys were 0.503 and $0.551 \mathrm{~V}_{\mathrm{SCE}}$, respectively, and the average $\mathrm{E}_{\mathrm{rp}}$ of the two alloys were 0.157 and $0.282 \mathrm{~V}_{\mathrm{SCE}}$, respectively. Thus, the slope of $\mathrm{E}_{\mathrm{pit}}$ versus [Ni] graph $\left(\Delta \mathrm{E}_{\mathrm{pit}} / \Delta[\mathrm{Ni}]\right)$ was $0.090 \mathrm{~V} \mathrm{wt} \%^{-1}$ and that of the $\mathrm{E}_{\mathrm{rp}}$ versus [Ni] graph $\left(\Delta \mathrm{E}_{\mathrm{rp}} / \Delta[\mathrm{Ni}]\right)$ was $0.231 \mathrm{~V} \mathrm{wt}^{-1}$. It was shown that the addition of only $0.57 \mathrm{wt} \%$ 
$\mathrm{Ni}$ increased both $\mathrm{E}_{\mathrm{pit}}$ and $\mathrm{E}_{\mathrm{rp}}$, and note that the beneficial effects of $\mathrm{Ni}$ were more pronounced in increasing $E_{\mathrm{rp}}$. In addition, it was also noted that the size of the cyclic polarization loop and the maximum current density were affected by the $\mathrm{Ni}$ addition. The maximum dissolution current density of the Ni03 alloy was $1.228 \mathrm{~mA} \mathrm{~cm}^{-2}$ and that of the Ni57 alloy was $0.687 \mathrm{~mA} \mathrm{~cm}{ }^{-2}$, on average. This observation is considered to be the reason for the higher value of $\Delta \mathrm{E}_{\mathrm{rp}} / \Delta[\mathrm{Ni}]$ than the $\Delta \mathrm{E}_{\mathrm{pit}} / \Delta[\mathrm{Ni}]$.

The increase in the current densities after the stable pit formation of the Ni03 and Ni57 alloys could be compared more clearly by Figure 6. Figure 6a exhibits the representative polarization curves of the Ni03 and Ni57 alloys chosen from Figure 5, and Figure 6b,c are the current-time curves as a result of potentiostatic tests on the two alloys. The potentiostatic tests were conducted in the same condition for the potentiodynamic polarization tests, that is a $2 \mathrm{M} \mathrm{NaCl}$ solution at $40{ }^{\circ} \mathrm{C}$, and the applied potentials were $0.35 \mathrm{~V}_{\mathrm{SCE}}$ (Figure $6 \mathrm{~b}$ ) and $0.10 \mathrm{~V}_{\mathrm{SCE}}$ (Figure $6 \mathrm{c}$ ). Under the anodic polarization at $0.10 \mathrm{~V}_{\mathrm{SCE}}$ (Figure $6 \mathrm{c}$ ), which was lower than the $\mathrm{E}_{\mathrm{rp}}$ of the two LDSSs, both alloys were passivated and a few current spikes indicating metastable pitting corrosion were observed in the current-time curves. On the other hand, applying $0.35 \mathrm{~V}_{\mathrm{SCE}}$ caused a stable pitting corrosion, that is, the initial passivation for a few seconds was followed by a continuous and irreversible increase in the current density (Figure $6 b$ ). Note that the current increase rate (i.e., $\Delta$ current/ $\Delta$ time) was faster in the Ni03 alloy than in the Ni57 alloy. It took approximately $500 \mathrm{~s}$ for the Ni03 alloy to reach the dissolution current of $500 \mu \mathrm{A}$, but for the Ni57 alloy, it needed approximately $1200 \mathrm{~s}$.
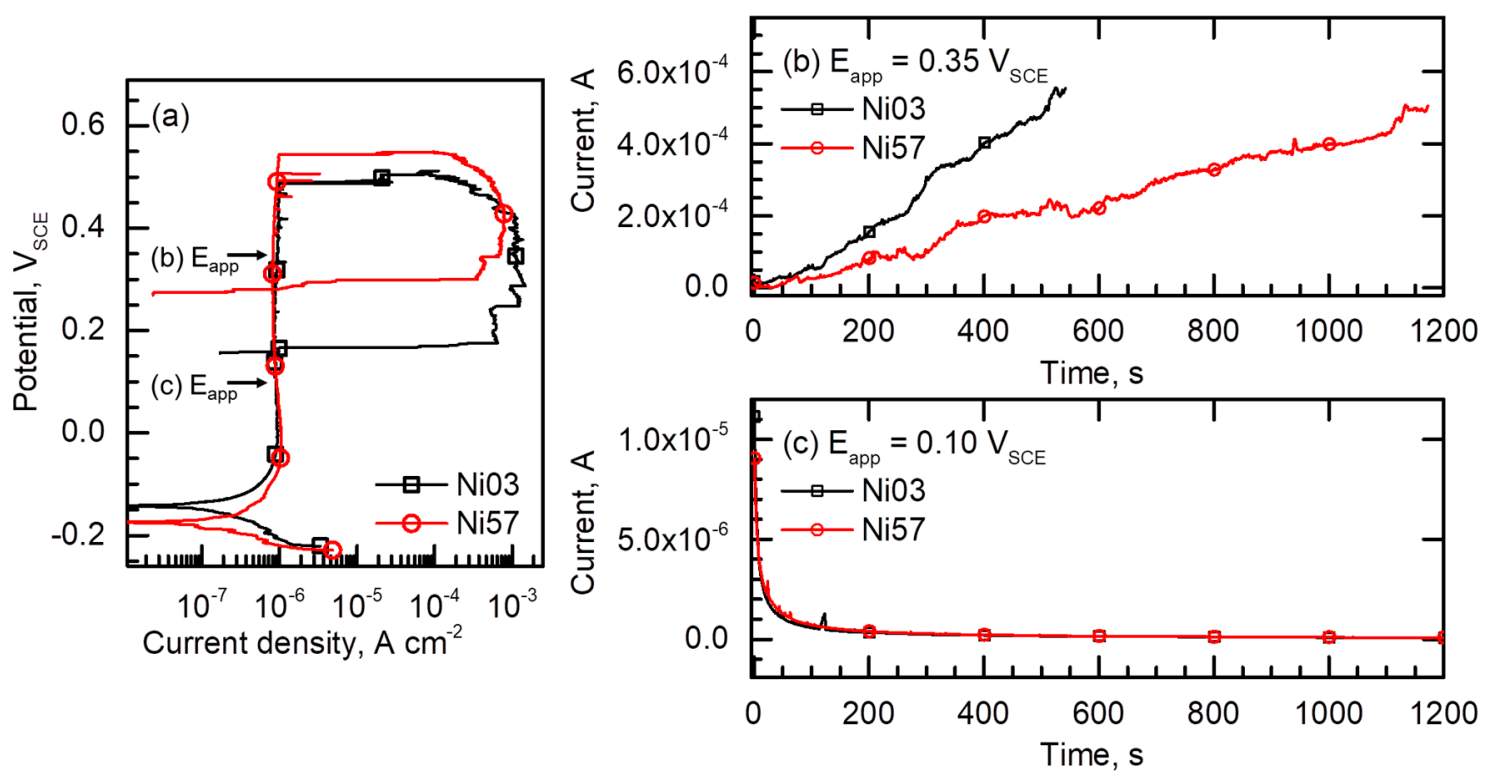

Figure 6. (a) Representative cyclic potentiodynamic polarization curves of the Ni03 and Ni57 alloys chosen from Figure 5a,b. Current-time curves of the Ni03 and Ni57 alloys obtained from potentiostatic tests measured in a $2 \mathrm{M} \mathrm{NaCl}$ solution at $40{ }^{\circ} \mathrm{C}$ under constant applied potentials ( $\mathrm{E}_{\text {app }}$ ) of (b) $0.35 \mathrm{~V}_{\mathrm{SCE}}$ and (c) $0.10 \mathrm{~V}_{\mathrm{SCE}}$.

Then, the initiation sites for the pitting corrosion were examined. The Ni03 and Ni57 specimens were immersed in a $1 \mathrm{M} \mathrm{HCl}+2 \mathrm{M} \mathrm{NaCl}$ solution at $40{ }^{\circ} \mathrm{C}$, and after $30 \mathrm{~min}$ of immersion, pitting corrosion occurred in both alloys. Figure 7a,b exhibit the pit morphologies of the Ni03 and Ni57 alloys, respectively. The stable pits, with a size of several $\mu \mathrm{m}$, were observed at the $\gamma$ side of the phase boundary for both DSSs. 

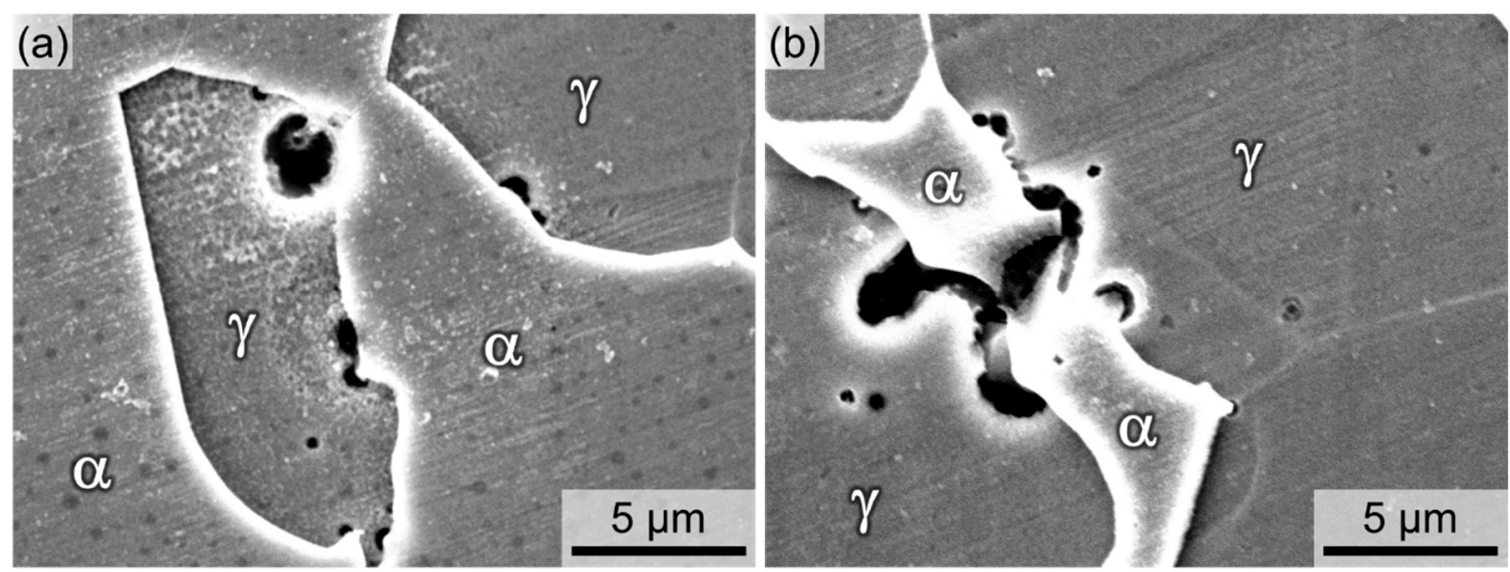

Figure 7. Pit morphologies of (a) Ni03 and (b) Ni57 alloys after immersion in a $1 \mathrm{M} \mathrm{HCl}+2 \mathrm{M} \mathrm{NaCl}$ solution at $40{ }^{\circ} \mathrm{C}$ for $30 \mathrm{~min}$.

\subsection{Uniform Corrosion Behavior}

Once a passive film is broken forming a pit embryo, the electrolyte confined in the pit cavity becomes acidified as the pit grows because of the hydrolysis reaction during the metal dissolution $[29,30]$. In the pit cavity, uniform dissolution begins to occur on the metal surface exposed to the acidified solution without passive film, and the uniform dissolution rate of metal determines the pit growth rate. Therefore, in order to compare the pit growth rates of the Ni03 and Ni57 alloys, the matrix dissolution rates were examined in the acidified chloride solution, simulating the electrolyte in the pit cavity.

Figure 8a shows the polarization behavior of the Ni03 and Ni57 alloys measured in a $1 \mathrm{M} \mathrm{HCl}$ solution at $40{ }^{\circ} \mathrm{C}$. In the strong acid, the two alloys exhibit typical active-passive transition during the anodic polarization. $\mathrm{E}_{\mathrm{corr}}$ of the Ni03 and Ni57 alloys were -0.485 and $-0.448 \mathrm{~V}_{\mathrm{SCE}}$, respectively, confirming that the Ni addition increases the nobility of the Ni03 matrix. From Figure 8a, the corrosion rate $\left(i_{\text {corr }}\right)$ and critical current density $\left(i_{\text {crit }}\right)$ were measured and the values were shown in Figure $8 b$. $\mathrm{i}_{\text {corr }}$ values of the $\mathrm{Ni} 03$ and Ni57 alloys were 0.754 and $0.486 \mathrm{~mA} \mathrm{~cm}^{-2}$, respectively, and $\mathrm{i}_{\text {crit }}$ values of the two alloys were 3.362 and $1.244 \mathrm{~mA} \mathrm{~cm}^{-2}$, respectively.
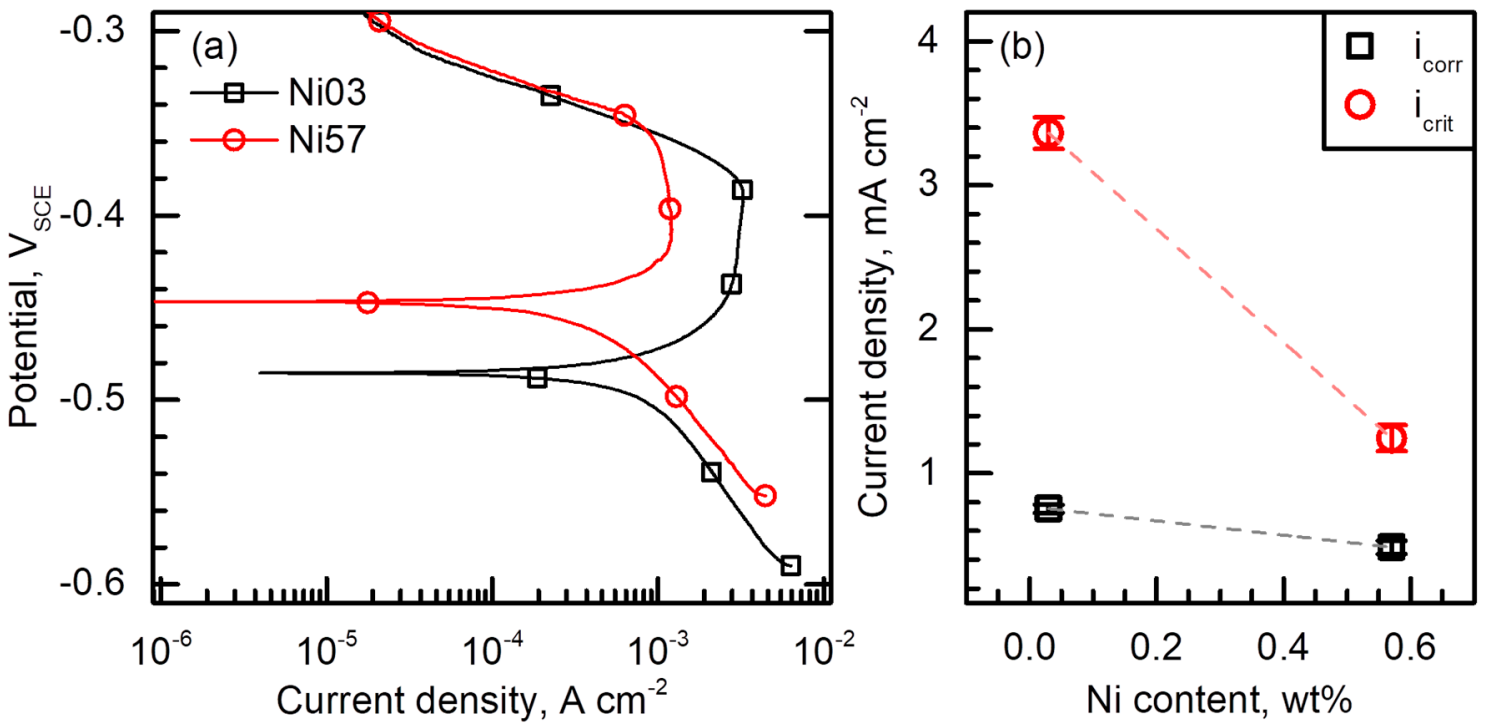

Figure 8. (a) Potentiodynamic polarization curves of the Ni03 and Ni57 alloys measured in a $1 \mathrm{M} \mathrm{HCl}$ solution at $40^{\circ} \mathrm{C}$ with a potential sweep rate of $0.17 \mathrm{mV} \mathrm{s}^{-1}$. (b) Corrosion rate $\left(i_{\text {corr }}\right)$ and critical anodic current density $\left(\mathrm{i}_{\text {crit }}\right)$ of the alloys. 


\subsection{Galvanic Corrosion Behavior}

The uniform dissolution rate of the LDSS matrix is inevitably related to the galvanic corrosion rate between the $\alpha$ and $\gamma$ phases. Thus, for the Ni03 and Ni57 alloys, the galvanic corrosion rates between the $\alpha$ and $\gamma$ phases were quantified by the measuring corrosion depth between the two phases. For this, the LDSS specimens were immersed in a $1 \mathrm{M} \mathrm{HCl}$ solution at $40{ }^{\circ} \mathrm{C}$, and the corrosion morphologies were examined using a surface profiler.

Figure 9(a-1,b-1) show three-dimensional topographic maps of the corroded Ni03 and Ni57 specimens, respectively, after immersion in the $\mathrm{HCl}$ solution. It is shown that the two constituent phases are different in corrosion rate in this strong acid solution. In both alloys, the more corroded phase (the blue phase) was the $\gamma$ phase, which was confirmed by the annealing twins. Then, the dissolution depth of the active phase $(\gamma$, in this case) relative to the noble phase $(\alpha)$ could be measured from Figure 9(a-2,b-2). Analyses on the contour maps revealed that the average corrosion depths of the $\gamma$ phase relative to that of the $\alpha$ were 0.51 and $0.34 \mu \mathrm{m}$ for the Ni03 (Figure 9(a-3)) and Ni57 alloys (Figure 9(b-3)), respectively. Thus, Figure 9 indicates that the addition Ni to the Ni03 alloy decreased the galvanic corrosion rate between the $\gamma$ and $\alpha$ phases.

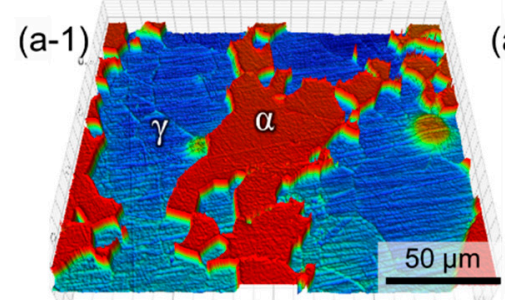

(a-2)

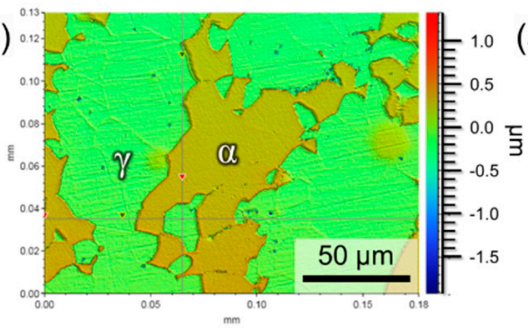

$(b-2)$

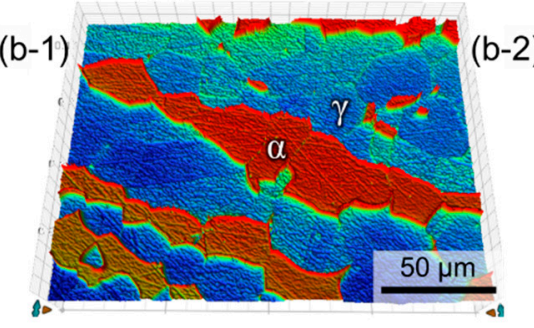

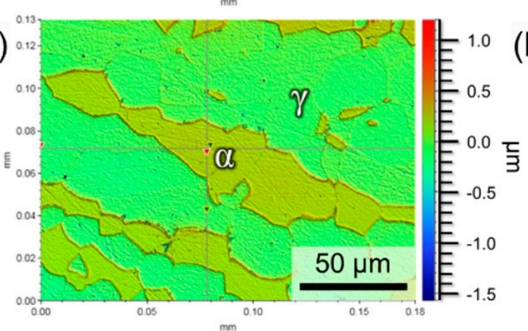
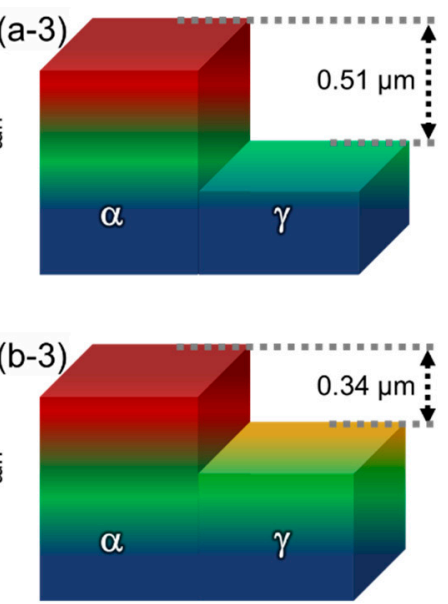

Figure 9. Three-dimensional topographs of the corroded surfaces of (a-1) Ni03 and (b-1) Ni57 alloys, and contour maps with a color scale bar of (a-2) Ni03 and (b-2) Ni57 alloys. The images were obtained after immersion in a $1 \mathrm{M} \mathrm{HCl}$ solution at $40{ }^{\circ} \mathrm{C}$ for $20 \mathrm{~min}$. Schematic diagram of the corrosion depths of (a-3) Ni03 and (b-3) Ni57 alloys.

\section{Discussion}

In the present paper, the Fe balance $-18 \mathrm{Cr}-7 \mathrm{Mn}-3 \mathrm{Mo}-3 \mathrm{~W}-0.4 \mathrm{~N}-(0.03,0.57) \mathrm{Ni}$ (in wt $\%)$ LDSSs were carefully fabricated and solution-treated. As shown in Figures 2 and 3, the two alloys exhibited similar microstructural characteristics, in terms of the grain size and the phase fraction. In addition, the second phases, such as $\mathrm{Cr}_{2} \mathrm{~N}$ and $\sigma$, were not observed in both LDSSs after the solution treatment. Figure 4 and Table 2 exhibited alloying element partitioning behavior into the $\alpha$ and $\gamma$ phases in both LDSSs. It was shown that the $\mathrm{Ni}$ addition to the bulk Ni03 matrix had negligible effect on the partitioning behavior of Mo, W, Mn, and N, and the difference in $\mathrm{Cr}$ concentrations between the $\alpha$ and $\gamma$ phases was slightly reduced in the Ni57 alloy comparing with the Ni03 alloy. In addition, Ni was preferentially partitioned into the $\gamma$ phase of the Ni57 alloy. The microstructural analyses suggested that the corrosion behavior of the Ni03 and Ni57 alloys were primarily affected by the chemical compositions of the constituent phases.

The pitting corrosion resistance of the two LDSSs was assessed by measuring the $\mathrm{E}_{\text {pit }}$ and $\mathrm{E}_{\mathrm{rp}}$ through the polarization tests in a $2 \mathrm{M} \mathrm{NaCl}$ solution at $40{ }^{\circ} \mathrm{C}$. Figure 5 indicated that the Ni addition to the Ni03 alloy increased both $\mathrm{E}_{\mathrm{pit}}$ and $\mathrm{E}_{\mathrm{rp}}$, and the positive effect of $\mathrm{Ni}$ was more pronounced in the 
increase in $\mathrm{E}_{\mathrm{rp}}$. Since higher $\mathrm{E}_{\mathrm{pit}}$ indicates higher resistance to the stable pit formation, and higher $\mathrm{E}_{\mathrm{rp}}$ means greater tendency for the pit extinction (i.e., repassivation), Figure 5 demonstrated that the Ni57 alloy possessed better resistance to pitting corrosion than the Ni03 alloy. In addition, it was also shown that the $\mathrm{Ni}$ addition reduced the size of the loop in the cyclic polarization curve, which implied that the alloying Ni retarded the pit growth rate. This observation was confirmed again by the measurement of the dissolution current after stable pit initiation of the two LDSSs (Figure 6b).

The uniform corrosion rate of the matrix has a strong correlation with the pit growth rate, and the uniform corrosion of dual-phase steel inside the pit is accompanied by the galvanic corrosion between the two phases. Thus, the uniform and galvanic dissolution rates between the two constituent phases were measured in the simulated solution inside the pit, that is, the acidified chloride solution, through the polarization tests (Figure 8) and immersion tests (Figure 9).

The polarization curves obtained in a $1 \mathrm{M} \mathrm{HCl}$ solution at $40{ }^{\circ} \mathrm{C}$ (Figure 8) indicated that the $\mathrm{Ni}$ addition to the $\mathrm{NiO} 3$ matrix enhanced the resistance to uniform corrosion, which was confirmed by reduced $i_{\text {corr }}$ and $i_{\text {crit }}$, and increased $E_{\text {corr }}$. That is, the dissolution rate of the Ni03 alloy in a strong acid containing chloride ions was faster than that of the Ni57 alloy under anodic polarization as well as under open circuit conditions. In addition, it was noted that the decrease in $\mathrm{i}_{\text {crit }}$ more sensitively depended on the [Ni] than $i_{\text {corr }}$, as shown in Figure 8 b. During the pit growth, the matrix inside the pit cavity exposed to the acidified chloride solution behaves as a local anode and the metal surface around the pit mouth behaves as a local cathode. Thus, in the pit cavity, active dissolution of the matrix under anodic polarization continues until the onset of the repassivation. For this reason, the significant decrease in the $\mathrm{i}_{\text {crit }}$ by the addition of $\mathrm{Ni}$ (Figure 8b) implied that the pit growth rate was slowed down by the addition of $\mathrm{Ni}$, which consequently assisted repassivation of both stable and metastable pits. Therefore, Figure $8 \mathbf{b}$ well explained the results from Figure $5 c$, that is, the Ni addition retarded the dissolution of the Ni03 matrix and consequently, increased the both $\mathrm{E}_{\mathrm{pit}}$ and $\mathrm{E}_{\mathrm{rp}}$.

The reduced $i_{\text {corr }}$ was found to be due to the suppressed galvanic corrosion rate between the $\alpha$ and $\gamma$ phases (Figure 9). From Figure 9, it was firstly noted that dissolution rates of the $\gamma$ and $\alpha$ phases were different, and the $\gamma$ phase was the more active phase than the $\alpha$ phase. Nobility of the $\alpha$ and $\gamma$ phases is determined by the chemical composition. The EPMA analysis results (Figure 4 ) showed that the $\gamma$ phases of both LDSSs contained higher $\mathrm{Cr}, \mathrm{Mn}$, and $\mathrm{N}$ concentrations than the $\alpha$ phase, and $\mathrm{Cr}$ and $\mathrm{Mn}$ are thermodynamically and galvanically more active than Fe. In addition, alloying $\mathrm{N}$ is reported to decrease the nobility of the FeCr-based alloy [31]. Thus, the $\gamma$ phase enriched with $\mathrm{Cr}$, $\mathrm{Mn}$, and $\mathrm{N}$ in the LDSSs dissolved more preferentially when it was in contact with the nobler phase, $\alpha$. For the Ni57 alloy, the added Ni was partitioned into the two phases, and the $\gamma$ phase contained $0.68 \mathrm{wt} \% \mathrm{Ni}$, while the $\alpha$ phase had only $0.42 \mathrm{wt} \% \mathrm{Ni}$. Still, the $\gamma$ phase of the Ni57 alloy was the relatively more active phase, but the $\mathrm{Ni}$ addition changed the corrosion depth. Thus, Figure 9 secondly indicated that the enrichment of $\mathrm{Ni}$ in the $\gamma$ phase of the Ni57 alloy resulted in reducing the dissolution rate of $\gamma$ galvanically coupled with the $\alpha$. The decreased galvanic corrosion rate of the Ni57 alloy showed a good agreement with the reduced $i_{\text {corr }}$ value of the Ni57 alloy shown in Figure 8.

Consequently, the reduced galvanic corrosion rate between the $\alpha$ and $\gamma$ phases and the increased resistance to uniform corrosion of the Ni57 alloy implied the decrease in the growth rate of the pit cavity, which was responsible for the increase in the potentials for the stable pit initiation (i.e., $\mathrm{E}_{\mathrm{pit}}$ ) and the pit extinction (i.e., $\mathrm{E}_{\mathrm{rp}}$ ) to the higher values accordingly.

The present study strongly suggests that controlling the galvanic corrosion rate between the constituent phases for DSSs is helpful to improve the resistance to pitting corrosion, and one of the effective ways to achieve the favorable resistance to pitting corrosion for the LDSS would be the use of small amount of Ni. The findings of this paper could be extended to other similar alloy systems.

\section{Conclusions}

In the present paper, LDSSs with a composition of Fe balance $^{-18 C r-7 M n-3 M o-3 W-0.4 N-(0.03,0.57) N i ~}$ (in $\mathrm{wt} \%$ ) were carefully fabricated and solution-treated. For the LDSSs, the microstructures, element 
partitioning, and the resistance to pitting corrosion were examined. Based on the results, the following conclusions could be drawn.

(1) The two alloys were found to have similar microstructures in terms of phase fraction and grain size, and to have a precipitation-free matrix. The composition analyses results suggested that the $\mathrm{Ni}$ addition to the Ni03 matrix had a negligible effect on the partitioning behavior of $\mathrm{Cr}, \mathrm{Mo}, \mathrm{W}$, $\mathrm{Mn}$, and N. Only Ni was preferentially partitioned into the $\gamma$ phase of the Ni57 alloy. Thus it was found that the corrosion behavior of the Ni03 and Ni57 alloys were primarily affected by the chemical compositions of the constituent phases.

(2) The polarization tests in a $\mathrm{NaCl}$ solution revealed that the addition of $\mathrm{Ni}$ was beneficial to improve the resistance to pitting corrosion, which was confirmed by increased $\mathrm{E}_{\mathrm{pit}}$ and $\mathrm{E}_{\mathrm{rp}}$, and the positive effect of $\mathrm{Ni}$ was more pronounced in the increase in $\mathrm{E}_{\mathrm{rp}}$. In addition, it was found that the $\mathrm{Ni}$ addition decreased the pit growth rate.

(3) The uniform corrosion behavior and galvanic dissolution rates between the two constituent phases were measured in the acidified chloride solution. As a result, it was shown that the Ni addition to the Ni03 matrix improved the resistance to uniform corrosion, and decreased the galvanic corrosion rate between the $\gamma$ and $\alpha$ phases, thus, the pit growth rate was decreased leading to improvement of the resistance to pitting corrosion.

Author Contributions: Conceptualization, H.-Y.H. and T.-H.L.; methodology, H.-Y.H. and T.-H.L.; software, J.H.J.; validation, S.-D.K., J.H.J., and J.M.; investigation, S.-D.K., J.M., and H.-Y.H; writing—original draft preparation, H.-Y.H. and S.-D.K.; writing-review and editing, T.-H.L.; funding acquisition, H.-Y.H. All authors have read and agreed to the published version of the manuscript.

Funding: This study was supported by the Basic Science Research Program of the National Research Foundation (NRF), funded by the Ministry of Science \& ICT (NRF-2019R1C1C1010246) and the Ministry of Trade, Industry \& Energy (MI, Korea) under Strategic Core Materials Technology Development Program (No. 10067375).

Conflicts of Interest: The authors declare no conflict of interest.

\section{References}

1. Lo, K.H.; Shek, C.H.; Lai, J.K.L. Recent developments in stainless steels. Mater. Sci. Eng. R 2009, 65, 39-104. [CrossRef]

2. Chail, G.; Kangas, P. Super and hyper duplex stainless steels: Structures, properties and applications. Procedia Struct. Integr. 2016, 2, 1755-1762. [CrossRef]

3. Ornek, C.; Engelberg, D.L. Towards understanding the effect of deformation mode on stress corrosion cracking susceptibility of grade 2205 duplex stainless steel. Mater. Sci. Eng. A 2016, 666, 269-279. [CrossRef]

4. Rossi, B. Discussion on the use of stainless steel in constructions in view of sustainability. Thin Walled Struct. 2014, 83, 182-189. [CrossRef]

5. Santos, T.F.A.; Torres, E.A.; Lippold, J.C.; Ramirez, A.J. Detailed Microstructural Characterization and Restoration Mechanisms of Duplex and Superduplex Stainless Steel Friction-Stir-Welded Joints. J. Mater. Eng. Perform. 2016, 25, 5173-5188. [CrossRef]

6. Boillot, P.; Peultier, J. Use of Stainless Steels in the Industry: Recent and Future Developments. Procedia Eng. 2014, 83, 309-321. [CrossRef]

7. Knyazeva, M.; Pohl, M. Duplex steels: Part I: Genesis, formation, structure. Metallogr. Microstruct. Anal. 2013, 2, 113-121. [CrossRef]

8. Mohammed, G.R.; Ishak, M.; Aqida, S.N.; Abdulhadi, H.A. Effects of Heat Input on Microstructure, Corrosion and Mechanical Characteristics of Welded Austenitic and Duplex Stainless Steels: A Review. Metals 2017, 7, 39. [CrossRef]

9. Vannevik, H.; Nilsson, J.-O.; Frodigh, J.; Kangas, P. Effect of elemental partitioning on pitting resistance of high nitrogen duplex stainless steels. ISIJ Int. 1996, 36, 807-812. [CrossRef]

10. Ha, H.-Y.; Lee, T.-H.; Lee, C.-G.; Yoon, H. Understanding the relation between pitting corrosion resistance and phase fraction of S32101 duplex stainless steel. Corros. Sci. 2019, 149, 226-235. [CrossRef] 
11. He, L.; Wirian, L.; Singh, P.M. Effects of Isothermal Aging on the Microstructure Evolution and Pitting Corrosion Resistance of Lean Duplex Stainless Steel UNS S32003. Metall. Mater. Trans. A 2019, 50, 2103-2113. [CrossRef]

12. Baddoo, N.R. Stainless steel in construction: A review of research, applications, challenges and opportunities. J. Constr. Steel Res. 2008, 64, 1199-1206. [CrossRef]

13. Kang, D.H.; Lee, H.W. Study of the correlation between pitting corrosion and the component ratio of the dual phase in duplex stainless steel welds. Corros. Sci. 2013, 74, 396-407. [CrossRef]

14. Zhao, Y.; Zhang, W.; Liu, Z.; Wang, G. Development of an easy-deformable Cr21 lean duplex stainless steel and the effect of heat treatment on its deformation mechanism. Mater. Sci. Eng. A 2017, 702, 279-288. [CrossRef]

15. Choi, J.Y.; Ji, J.H.; Hwang, S.W.; Park, K.-T. Strain induced martensitic transformation of Fe-20Cr-5Mn-0.2Ni duplex stainless steel during cold rolling: Effects of nitrogen addition. Mater. Sci. Eng. A 2011, 528, 6012-6019. [CrossRef]

16. Guo, Y.; Sun, T.; Hu, J.; Jiang, Y.; Jiang, L.; Li, J. Microstructure evolution and pitting corrosion resistance of the Gleeble-simulated heat-affected zone of a newly developed lean duplex stainless steel 2002. J. Alloy. Compd. 2016, 658, 1031-1040. [CrossRef]

17. Ha, H.-Y.; Lee, T.-H.; Kim, S. Effect of W on Stress Corrosion Cracking Susceptibility of Newly Developed Ni-Saving Duplex Stainless Steels. Met. Mater. Int. 2017, 23, 115-125. [CrossRef]

18. Ha, H.-Y.; Lee, C.-H.; Lee, T.-H.; Kim, S. Effects of Nitrogen and Tensile Direction on Stress Corrosion Cracking Susceptibility of Ni-Free FeCrMnC-Based Duplex Stainless Steels. Materials 2017, 10, 294. [CrossRef]

19. Ha, H.-Y.; Lee, T.-H.; Hwang, B.C. High-Performance High-Nitrogen Duplex Stainless Steels Excellent in Pitting Corrosion Resistance. U.S. Patent 9,663,850, 30 May 2017.

20. Ha, H.-Y.; Lee, T.-H.; Kim, S.-J. Synergistic effect of Ni and $\mathrm{N}$ on improvement of pitting corrosion resistance of high nitrogen stainless steels. Corros. Eng. Sci. Technol. 2014, 49, 82-86. [CrossRef]

21. Azuma, S.; Kudo, T.; Miyuki, H.; Yamashita, M.; Uchida, H. Effect of nickel alloying on crevice corrosion resistance of stainless steels. Corros. Sci. 2004, 46, 2265-2280. [CrossRef]

22. Yoon, Y.-S.; Ha, H.-Y.; Lee, T.-H.; Kim, S. Comparative study of stress corrosion cracking susceptibility of Fe18Cr10Mn- and Fe18Cr10Mn1Ni-based high nitrogen stainless steels. Corros. Sci. 2014, 88, 337-348. [CrossRef]

23. Ha, H.-Y.; Jang, M.-H.; Lee, T.-H.; Moon, J. Interpretation of the relation between ferrite fraction and pitting corrosion resistance of commercial 2205 duplex stainless steel. Corros. Sci. 2014, 89, 154-162. [CrossRef]

24. Ha, H.-Y.; Jang, M.-H.; Lee, T.-H.; Moon, J. Understanding the relation between phase fraction and pitting corrosion resistance of UNS S32750 stainless steel. Mater. Charact. 2015, 106, 338-345. [CrossRef]

25. Yoon, H.; Ha, H.-Y.; Lee, T.-H.; Kim, S.-D.; Jang, J.H.; Moon, J.; Kang, N. Pitting Corrosion Resistance and Repassivation Behavior of C-Bearing Duplex Stainless Steel. Metals 2019, 9, 930. [CrossRef]

26. Park, J.H.; Kang, Y. Inclusions in Stainless Steels-A Review. Steel Res. Int. 2017, 88, 1700130. [CrossRef]

27. Ha, H.Y.; Park, C.J.; Kwon, H.S. Effects of non-metallic inclusions on the initiation of pitting corrosion in $11 \%$ Cr ferritic stainless steel examined by micro-droplet cell. Corros. Sci. 2007, 49, 1266-1275. [CrossRef]

28. Ha, H.Y.; Park, C.J.; Kwon, H.S. Effects of misch metal on the formation of non-metallic inclusions and the associated resistance to pitting corrosion in 25\% Cr duplex stainless steels. Scr. Mater. 2006, 55, 991-994. [CrossRef]

29. Newman, R. Pitting corrosion of metals. Electrochem. Soc. Interface 2010, 19, 33-38. [CrossRef]

30. Frankel, G.S. Pitting corrosion of metals a review of the critical factors. J. Electrochem. Soc. 1998, 145, $2186-2198$. [CrossRef]

31. Ha, H.-Y.; Lee, T.-H.; Kim, S.-J. Role of nitrogen in the active-passive transition behavior of binary $\mathrm{Fe}-\mathrm{Cr}$ alloy system. Electrochim. Acta 2012, 80, 432-439. [CrossRef]

(C) 2020 by the authors. Licensee MDPI, Basel, Switzerland. This article is an open access article distributed under the terms and conditions of the Creative Commons Attribution (CC BY) license (http://creativecommons.org/licenses/by/4.0/). 